\title{
Two letters from Charles Darwin in the epistolary collection of the Geological Commission of the Kingdom (Portugal)
}

\section{Duas cartas de Charles Darwin no acervo epistolar da Comissão Geológica do Reino (Portugal)}

\author{
JOSÉ M. BRANDÃO \\ Centro de Estudos de História e Filosofia da Ciência (CEHFCi) | Universidade de Évora, Portugal
}

\begin{abstract}
During his long scientific life, Darwin established contacts with correspondents around the world. In Portugal, to date, only knew the letters sent to the Azorean naturalist Arruda Furtado, but during the cataloging work in progress, of the documents of the former Geological Commissions, appeared two letters signed by the famous naturalist, likely to be addressed to Carlos Ribeiro, thanking him for sending publications.

The fact that Darwin did not mention the works received, leaving just notice that the ones referred to the prehistoric remains and Tertiary formations in Portugal, leaves some doubt in their clear identification, thus allowing the possibility of admitting Ribeiro had present him with the question of the tertiary man, based on the discovery of eoliths' in the Tagus Valley, in the early 1860s.
\end{abstract}

Key Words correspondence - Charles Darwin - Carlos Ribeiro - tertiary man

RESUMO Durante a sua longa vida científica, Darwin estabeleceu contato com correspondentes do mundo todo. Em Portugal, até a data, apenas eram conhecidas as cartas enviadas ao naturalista açoriano Arruda Furtado; porém, no decurso do trabalho de catalogação do acervo documental das antigas Comissões Geológicas, apareceram duas cartas assinadas pelo famoso naturalista, provavelmente dirigidas a Carlos Ribeiro, agradecendo o envio de publicações. O fato de Darwin não se referir às obras recebidas, deixando apenas perceber que se referiam aos vestígios pré-históricos e formações terciárias em Portugal, deixa algumas dúvidas na sua clara identificação, permitindo, assim, admitir a possibilidade de Ribeiro ter procurado apresentar-lhe a questão do homem terciário, alicerçada na descoberta dos eólitos do Vale do Tejo, no início da década de 1860.

Palavras-chave correspondência - Charles Darwin - Carlos Ribeiro - homem do terciário

Les heureux résultats qui avaient couronné les recherches [...] dans les calcaires de Beauce, à Saint Prest [...] prouvèrent que l'homme préhistorique appartient à une époque géologique bien plus reculée que celle qui se nomme diluviale ou quaternaire; c'est-à-dire que l'homme a fait partie, non seulement de la faune pliocène, mais encore de la faune miocène.

C. Ribeiro (1872) 


\section{Introduction}

Correspondence sent and received by Charles Darwin (1809-1882) during his long scientific life is currently estimated at more than 15,000 documents exchanged with about 2,000 correspondents around the world. Started to compile by Francis Darwin, son of the naturalist, ${ }^{1}$ this correspondence has been systematically studied and published by several authors.

The recent database Darwin Correspondence Project at Cambridge University provides a broad view of that universe of correspondents with the naturalist, as well as to accede online to a significant part of the documents dispersed in different institutions.

In Portugal, to date, only knew the letters addressed by Darwin to the Azorean naturalist Arruda Furtado (18541887) with several suggestions of work in line with his own lines of interest, transcribed and analyzed in 1957 by the botanist of the University of Lisbon Carlos Tavares (1914-1972). ${ }^{2}$ Recently, during the cataloging work of the historical archives deposited in the National Laboratory for Energy and Geology (LNEG) we found two inedited letters signed by the famous naturalist where he thanks publications sent by the former Geological Commission of Portugal.

This finding raises, however, several questions, particularly with regard to identification of works that have been offered and about the motivations that may have justified the wording of these two letters, issues that are discussed in this text.

\section{Letters: characterization and transcription}

The documentary collection of the Geological and Mining History Archive of LNEG (Arquivo Histórico Geológico e Mineiro (AHGM)), hereinafter referred to briefly by AHGM, resulted from the continuous accumulation of some thousands of scientific documents (letters, reports, map drawings and iconography) generated or received by the Portuguese pioneer organizations in the survey of the Geology of the national territory: the several Comissões Geológicas (Geological Commissions) (1848-1918) and the Serviços Geológicos de Portugal (Portuguese Geological Survey) who succeeded those early bodies (1918-1993).

Taken as a whole, this archive is a secure and unique basis for the study of the history and practice of Geosciences in Portugal outside the universities, as recent works by several investigators have shown.

Darwin's letters were among the many documents included in the fund Geological Commissions (PT LNEGCG). Written on $25.4 \times 20.2 \mathrm{~cm}$ white sheets, folded in half, with "Joynson Superfine" watermarks, they are stamped with the address of Down House, the residence where the naturalist settled with his family in 1842.

Although the letters were not personally or institutionally endorsed, the combination of the themes indicated in the letters, a word of thanks for the work of the Commission on the prehistoric remains in Portugal and the tertiary formations, with the postal dates of February 1879 and of November 1880, identify, with some certainty, the intended recipient: clearly the engineer Carlos Ribeiro (1813-1882), author of several papers on both topics. It is, however, unclear whether the letters were addressed to him as an institutional figure, director of the Geological Survey, or as the scientist-archaeologist. Unfortunately the envelopes were not archived therefore we cannot confirm or reject these hypothesis.

\section{Transcriptions ${ }^{3}$}

Calendar no. 11887f, log no. 21550 / PT LNEGCG02.03.281

[To Carlos Ribeiro] 17 February 1879 
Down, | Beckenham, Kent

Febr. 17th 1879. -

Dear Sir

I beg leave to thanks you very sincerely for your great kindness in having sent me your fine work on Prehistoric Remains. -

I remain with much respect - | Dear Sir | Yours faithfully | Charles Darwin

Calendar no. 12857f, log no. 21551 / PT LNEGCG02.03.288

[To Carlos Ribeiro] 25 November 1880

Down, | Beckenham, Kent

November 25. 1880

Dear Sir

I am much obliged to you for your great kindness in having sent me your great work on Prehistoric Remains in Portugal \& for your paper on Tertiary formations.

With much respect - I remain | Dear Sir | Yours faithfully \& obliged | Charles Darwin

Textual notes:

Kent.] between brackets 'Railway Station | Orpington. S.E.R.'

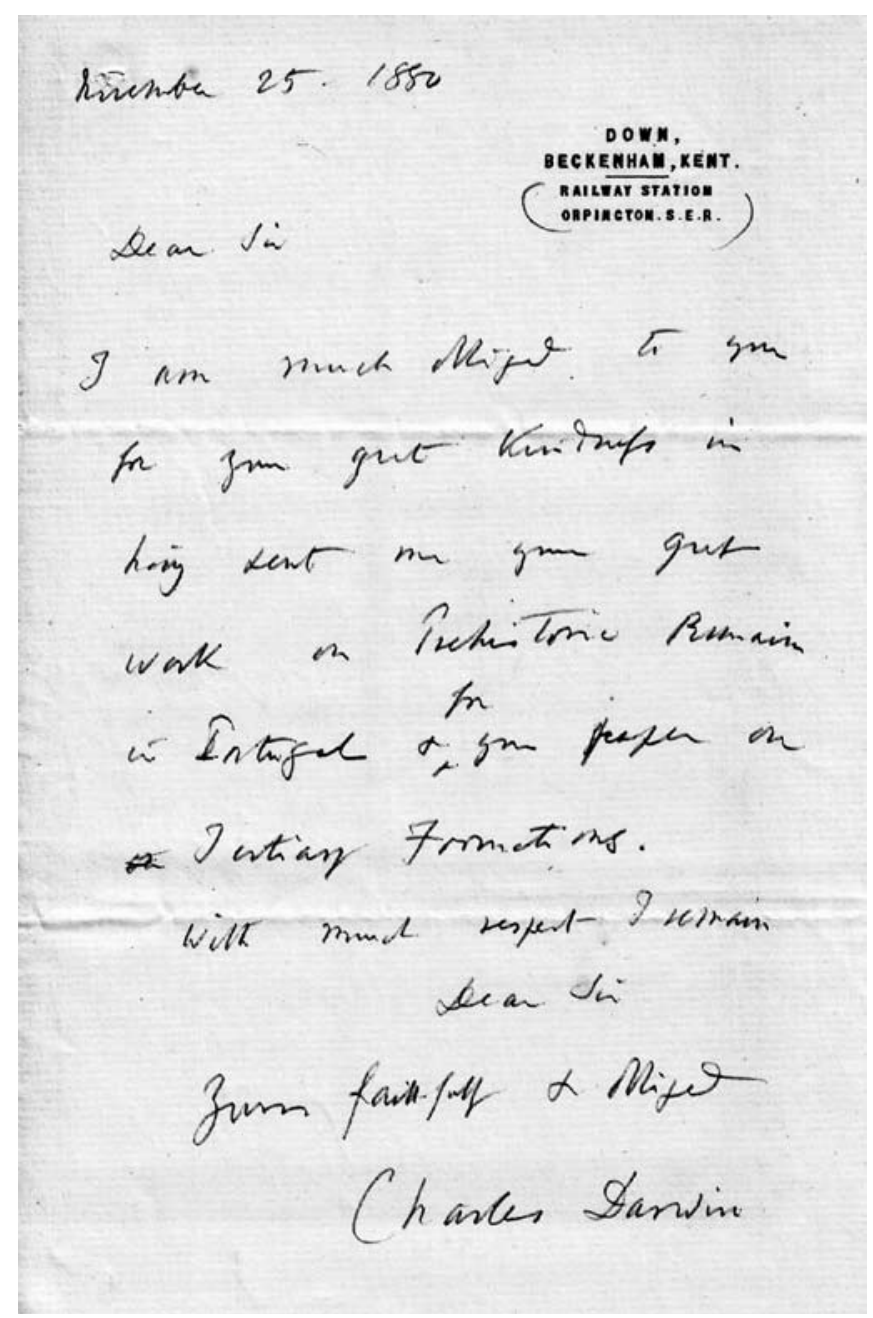

Figure 1 One of Darwin's letters. By courtesy of Laboratório Nacional de Energia e Geologia (LNEG) 


\section{The publications darwin received}

Considering the dates of the letters, the first hypothesis that we proposed for the identification of the publications was that Darwin was possibly acknowledging the receipt of two issues of Estudos prehistóricos em Portugal (Prehistoric studies in Portugal), presented by Carlos Ribeiro to the Royal Academy of Sciences, Lisbon, and published on the same year as the letters. ${ }^{4}$

In the first of these publications, titled Noticia da estação humana de Licêa (News of the human site Licea), Ribeiro describes in detail the archaeological site located on the outskirts of Lisbon, as well as the most important findings. In the second one, Monumentos megalithicos das visinhanças de Bellas (Megalithic monuments in the vicinity of Belas), the author describes in detail the prehistoric site, the osteological remains and funerary objects unearthed, some of which were displayed at the Trocadéro Museum em1878, at the Paris Universal Exhibition.

The examination of the lists and entry books concerning the publications offered by the Geological Commission, where the following entry is registered: "Darwin, Charles, Esq, Down, Beckenhan, Kent", show that the naturalist, as well as his countrymen's Lyell, Phillips and Murchison, was part of a group of notable national and foreign personalities, who were regularly sent published works. Therefore, Darwin would have received at least the works listed in Table 1, thus confirming the hypothesis concerning the remittance of Estudos. ${ }^{5}$

Table 1. Publications of the Geological Commission of Portugal sent to C. Darwin

\begin{tabular}{llcc}
\multicolumn{1}{c}{ Author } & Title & $\begin{array}{c}\text { Year of } \\
\text { publication }\end{array}$ & Source \\
Bernardino Gomes & $\begin{array}{l}\text { Fossil flora from the carboniferous ground in the vicinity of Porto, } \\
\text { Serra do Bussaco and Moinho d'Ordem near Alcácer do Sal }\end{array}$ & 1865 & a) \\
\hline Pereira da Costa & News on the human skeletons discovered in Cabeço da Arruda & 1865 & b) \\
\hline Nery Delgado & Caves of Cesareda & 1867 & c) \\
\hline Nery Delgado & Silurian lands in Baixo Alentejo & 1876 & c) \\
\hline Carlos Ribeiro e & Geological map of Portugal & {$[1878 ?]$} & c) \\
Nery Delgado & & 1878 & c) \\
\hline Carlos Ribeiro & Prehistoric studies - Leceia (I) & 1880 & c) \\
\hline Carlos Ribeiro & Prehistoric studies - Megalithic monuments (II) & 1880 & c)
\end{tabular}

a) "List of the national scientific establishments and of the notable people in Portugal, due their social position and culture, to whom the Commission offered its publications", [186-?]. AHGM.

b) "List of the national and international scientific establishments, societies, public libraries and of notable people, due to their culture or social position, to whom, besides the author, the work titled Noticia sobre os esqueletos humanos descobertos no Cabeço da Arruda (News about the human skeletons discovered in the Cabeço Arruda) was distributed by the Geological Commission of Portugal", [186-?]. AHGM.

c) Entry book for the publications distributed by the Geological Commission, [1882?]. AHGM. Note: There is no record of delivery dates of these publications. 
These documents do not prove that have been sent to Darwin other works, such as Ribeiro's important monograph presented in 1871 to the Royal Academy of Sciences, Descripção de alguns silex e quatzites lascados encontrados nas camadas dos terrenos terciario e quaternario das bacias do Tejo e Sado (Description of some chipped flint and quartzite found in layers of Tertiary land and quaternary basin of the Tagus and Sado). In this work, the author describes in detail the lithic objects of Tagus Valley, which he believed had been purposefully shaped and that fuelled the controversial question of Portuguese tertiary man for years. These objects were later considered eoliths. We reasoned that this Ribeiro's monograph could have been one of the works to which the letters refer, despite the time elapsed between the publication and Darwin's letters. ${ }^{6}$

There is also some doubt regarding the reference to a paper on the Tertiary formations, of which there is no record in the entry book concerning offers. We believe that it might be a stratigraphic note presented by Ribeiro at the International Geological Congress in Paris in 1878. ${ }^{7}$ However, in view of its importance we should also state the possibility that it is the note on the geological position of the layers, where Ribeiro collected the chipped flint that he presented at the Congress of Brussels. ${ }^{8}$

\section{Discussion}

Among the various issues that arise, the main one is, undoubtedly, the reason that prompted Darwin to write these two letters. He had previously received publications from the Geological Commission and there are no records of a similar procedure. We can therefore assume that he had special reasons, such as the recognition by the naturalist of the relevance of the work or of the reputation of its author, arising from their participation in international meetings. However, this fact could result, instead, of an attempt by Ribeiro to establish a personal contact with Darwin, of which no record was found.

At the time of the publication of the Origin of Species in 1859, the newly formed Geological Commission was still moving to new premises on the second floor in the building of the Academy of Sciences to where it had moved in April of that year. Its two-man direction had been assigned to Carlos Ribeiro, an engineer by the Polytechnic Academy of Porto and senior inspector of Mines, and Pereira da Costa (1809-1889), a graduate in Medicine from the University of Coimbra, professor of geology and mineralogy at the Polytechnic School of Lisbon. Nery Delgado (1835-1908) was appointed as deputy-director and later succeeded Ribeiro as the head of that institution. The first steps were then being taken in the geognostic survey of the country, started in previous years with the work of Frenchman Charles Bonnet (1816-1867), who headed the first Commission (Geologic and Mineralogical Commission of the Kingdom) created in 1848 within the Royal Academy of Sciences.

Those men had a herculean task ahead of them made even worse by the difficulties related to the lack of a broad technical team and topographic coverage of the country they needed. ${ }^{9}$ However, these facts were not an obstacle to the development of active research, combining field and office work with the drafting of scientific monographs and the organization of a museum that still exists today, where samples and collections of comparison were exhibited in an organized scientific fashion. ${ }^{10}$

\section{The commission and the study of prehistoric archaeology}

Although the main purpose of the Geological Commission was to carry out a geological survey of the country and to draw a geological map, its intervention quickly spread to other areas requiring knowledge of Geology and extended to issues related to the presence and study of the activities of prehistoric man on national soil. It should be noted, 
incidentally, that the discussion of the existence of an antediluvian man was then the subject of warm discussion. Discoveries made since the 1820s in various parts of central Europe, of flint objects and human skeletons along with bones of extinct animals stirred up the scientific community. These findings demonstrated that man coexisted with such extinct animals, and was therefore more ancient than previously thought.

Carlos Ribeiro came to nurture a particular interest in these matters that, strictly speaking, belonged to both geology and archaeology.
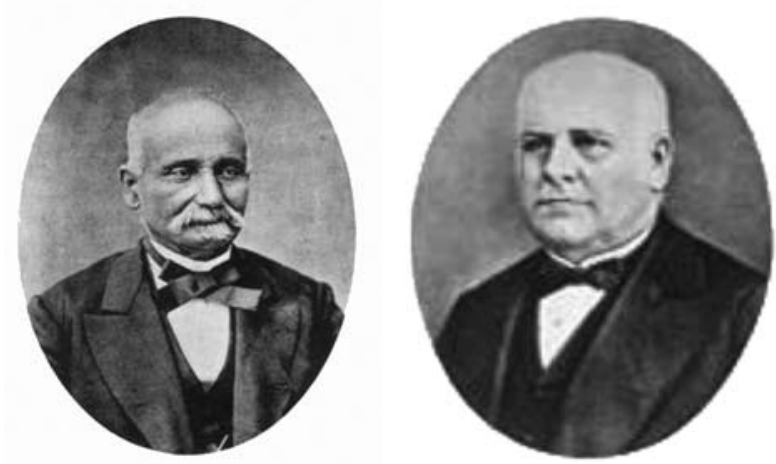

Figure 2 Carlos Ribeiro (1913-1882) and Pereira da Costa (1809-1889). Archives photographs, AHGM

Possibly excited by the discoveries of Boucher de Phertes (1788-1868) in the faluns of Touraine, France, Ribeiro undertook several studies on the formation of the Tagus valley, shortly after taking over the position at the Geological Commission. He attributed, overall, a Tertiary age to the Geological Map of Spain and Portugal drawn by Verneuil and Collomb (1864). These works were intended to establish the geological history of the deposits and obtain objects of human industry belonging to the prehistoric period.

Lorsqu'en 1860 s'agitait entre les savants la question de l'antiquité de l'homme sur la terre, je me souviens d'avoir donné [...] des instructions aux collecteurs de cette Commission, pour bien explorer les vallées du Tage et do Sado, dans le but d'y recueillir des donnés qui pussent jeter quelque lumière sur la question des oscillations de notre sol pendant la période post-tertiaire et nous éclaires sur celle de la présence de l'homme dans nos régions, dans les temps préhistoriques. ${ }^{11}$

His discovery in 1863, in Cabeço da Arruda (Muge), of a series of mounds of brackish water mollusc shells and mammalogical remains, within which were found several skeletal evidence of human burials and various bone and lithic artefacts, ${ }^{12}$ added to the collections of flint and quartzite objects in which the geologist found signs of human labour.

These findings will have been motivation enough for the members of the Geological Commission to carry out, in the following years, further investigations in this field. In particular, it is noteworthy to mention the exploration of caves in the Maciço Calcário Estremenho (Jurassic limestone massif of Estremadura) and the cave of Furninha by Nery Delgado, who found and reported several findings of human activities and skeletons as well as large sets of remains of extinct animals of the Quaternary. ${ }^{13}$

For his part and among other works he had to attend to, Ribeiro also explored, in addition to the megalithic monuments, the caves of the Poço Velho in Cascais and oversaw the study of artificial caves at Quinta do Anjo (Palmela) and of the Neolithic village of Leceia. The latter were carried out in the second half of the seventies. ${ }^{14}$ Meanwhile, Pereira da Costa published the first results of the study of the human remains discovered in the shell mounds of Muge $(1865)^{15}$, which he compared with kjökkenmödings from Denmark. In the following year he published an illustrated work on the Portuguese megalithic monuments, with a detailed description of their osteological remains and discovered buried artifacts. 


\section{The tertiary man}

Of all the archaeological work done by members of the Commission, Ribeiro's lithic findings in the Miocene formations near Carregado and Alenquer were perhaps the ones that attracted most attention due to the unexpected results they revealed.

De 1860 á 1863, je porté mes investigations sur les objets de l'industrie humaine préhistorique ensevelis en Portugal, dans les dépôts quaternaires. C'est alors que j'appris que, dans les couches tertiaires qui se trouvent entre Carregado et Alenquer, deux petites villages situés de 35 à 40 kilomètres au NNE de Lisbonne, il se trouvait des silex taillés [...] je les poussai dans plusieurs directions et je trouvai, dans l'intérieur même des couches de calcaire, de marne et de grés, des éclats de silex et de quartzite travaillé. ${ }^{16}$

Later (1905) Nery Delgado explained: These stones, eoliths, pointed to the existence in the Miocene period of an intelligent being that chipped the flint exactly like the quaternary man. ${ }^{17}$

At first we tried to delude ourselves; we tried to convince ourselves that these chipped flint and quartzite were not the result of any human work, hence arguing against the evidence of their presence. However, as the collecting of these objects grew, and the conditions of their deposit became better known, it strengthened our belief [...] that these stones had been fashioned by man's hand before becoming buried in the layers where we excavated them. ${ }^{18}$

Although the stratigraphic and tectonic evidence did not leave the author much room for doubting the age of the formations where he had gathered the presumable stone artefacts, the uncertainty about the timing of such "industries" remained for several years. The author later reconsidered their age thinking they might be quaternary, as the work published in 1866 suggests: ${ }^{19}$

At the time (1863 to 1866), Ribeiro wrote (id. ibid.) we were not well informed about the discussions that were going on between the scientists about the antiquity of prehistoric man. [...]. Therefore, we were led to believe that the unpolished chipped stone only appear in the Quaternary deposits and in the more recent ones.

The release of the latest findings of carved flint in Pontlevoy by the Abbot Louis Bourgeois (1819-1878), dispelled any doubts Ribeiro might have had, and allowed him to defend the thesis that man existed prior to diluvium, thus dating from the tertiary. Bourgeois firmly defended these ideas at the International Congress of Archaeology in Paris in 1867, held under the international exhibition he helped to organize. ${ }^{20}$ However, as reported by the great pre-historian Gabriel Mortillet (1821-1898), because the opinions of those present were divided the Congress ne lui fait faire ni un pas en avant ni un pas en arrière. ${ }^{21}$

According to Delgado (1905), when he presented those exceptional objects to the participants of the Congress of Brussels in August 1872, where he had taken a series of samples, Carlos Ribeiro had already surpassed the dilemma he had faced. He had returned to his original idea without wavering as to the authenticity of the archaeological field, nor about the meaning of the objects found as stated.

A cette époque, l'homme quaternaire était encore un fait fort controversé; comment donc aurais-je été reçu si j'étais venu annoncer l'homme tertiaire ! [...] Je me trouvai en présence d'un dilemme dont les deux alternatives m'effrayaient: ou rejeter mon propre témoignage, c'est-à-dire, nier que les pierres taillées que j'avais ramassées dans les dépôts tertiaires, n'aient jamais passé par la main de l'homme, ou affirmer que l’immense dépôt que j'avais devant moi, appartenait à la période quaternaire. ${ }^{22}$ 
The thesis of tertiary man was again advanced by Ribeiro at the congress of Paris in 1878, supported by the lithic findings exhibited in Trocadéro and by the fact that the levels where they were found contained fossils of vertebrates Hipparion gracilis, Mastodon angustidens, Rhinoceros minutus etc. characteristic of the upper Miocene.23

The importance accorded to this issue, by the international scientific community, justified the holding in Lisbon of the 9th session of the Congress of Prehistoric Archaeology and Anthropology in 1880. During the Congress, Ribeiro presented again his findings ${ }^{24}$ and the participants had the opportunity to see the materials exhibited at the Museum of Anthropology of the Commission ${ }^{25}$ that Ribeiro and Delgado had collected over many years of work and they took excursions to some of the major archaeological sites they had excavated.

L'existence de l'homme dans nos latitudes, à l'époque miocène, est un sujet des plus intéressantes sur lequel nous avons voulu appeler l'attention du Congrès. Cette question, discutée en diverses sessions antérieures, est à résoudre: cependant les faits recueillis en Portugal s'offrent sous un tel aspect qu'ils aideront, nous osons le croire, à élucider la question; et qu'après meilleur examen des localités et après les discussions que l'importance du sujet réclame, le Congrès arrivera à formuler ses idées à cet égard. ${ }^{26}$

We should add that the Lisbon Congress failed to reach a clear verdict on the issue, as Paul Choffat (1849-1919), ${ }^{27}$ geologist of the Geological Commission, emphasized, keeping the issue of tertiary man open for a few more decades. ${ }^{28}$

\section{The relationship with Darwin and his scientific work}

The study of the Geological Commission's correspondence has demonstrated the existence of a wide range of international correspondents with whom its members kept working and personal relationships that, in some cases, functioned as true "bridges" of Portuguese diplomacy. ${ }^{29}$ However, the existence of a relationship with Darwin was unknown, and this fact deserves some reflection.

It seems legitimate to formulate two sets of questions: one related to how the work, or notoriety, of the naturalist had come to the attention of Carlos Ribeiro, and second, those concerning the understanding of scientific contributions or reflections, which Darwin's ideas could bring to the future Commission's work.

Although part of the latter question deserves an analysis that is outside the scope of this paper, it should be noted that Ribeiro, while an expert in Natural Sciences, was not a palaeontologist and thus lacked sensitivity to the systematic issues or phyletic relationships between biologic groups. The determination of the fossils, most often made by his colleague Pereira da Costa, interested him only, as an essential tool to separate, and date, geological formations. Moreover, his texts do not indicate any evolutionary inclination, nor does this way of looking at the natural world transpire in the monographs of Pereira da Costa, particularly in the Molluscos fosseis dos depositos terciários (Fossil molluscs of tertiary deposits) (1866-1867), structured according to Lamarck's "families".

Nor do we have evidence that there was any particular orientation regarding the organization of the museum's paleontological collections, traditionally arranged according to zoological order as Delgado refers (1901), and reflecting quite possibly the systematics of D'Orbigny. ${ }^{30}$

Because it is not straightforward to establish a direct relationship between Darwin's and the Comission's work through palaeontology or geology, a field that the great naturalist explored before settling in the study of the variation of biological species. So, the possibility remains to consider key issues the questions of origin and antiquity of man, which strongly attracted the attention of Ribeiro, because the idea of evolution had on them major implications as stated by Godrum (2009). ${ }^{31}$ It should be added that this time, the man was still often regarded, as separate from the rest of biological species, as Linnaeus postulated and Charles Lyell (1797-1875), among others, had come to defend. 
With regard to the understanding of the route through which news of Darwin had reached the Geological Commission, there are many possibilities albeit all open for lack of documentation that would allow to determine the correct one in a sustained manner.

Ribeiro, being a man of culture, certainly would not have missed the publication of Beagle's reports, since at the time the literature of scientific travels was fashionable. We should note in support of this idea, the existence among the group of works from the library of the Commission of a copy of Geological observations in South America... (see Table 2) stamped by the Bureau of Mines, an official agency where Ribeiro worked between 1852 and 1857. ${ }^{32}$ Without excluding the possibility that the information reached him through the various personalities of international geology, with whom Ribeiro socialized or maintained contact since his long trip through Europe in 1858, we are inclined to believe that the news may have arrived via Pereira da Costa. In turn Pereira da Costa learned the news form the Professor of botany at the University of Coimbra, Julio Henriques (1838-1928). The latter has been unanimously appointed as a pioneer in Portugal in the dissemination of the ideas contained in Darwin's Origin of Species. ${ }^{33}$

It is known that Darwin appears on the lists of recipients of the Commission's publications and there are, in the library of this old institution, some of his works (Table 2), which were acquired before 1882. The 1882 inventory that we had access to include a French translation of the Origin of species published in 1862, that Ribeiro had requested for his personal use. ${ }^{34}$

Table 2. Works by C. Darwin in the library of the geological commission

\begin{tabular}{clc} 
Registration & \multicolumn{1}{c}{ Title } & \multicolumn{1}{c}{$\begin{array}{c}\text { Place and year of } \\
\text { publication }\end{array}$} \\
\hline 529 & $\begin{array}{l}\text { Geological observations on the volcanic islands visited during the } \\
\text { voyage of Beagle }\end{array}$ & London, 1844 \\
\hline 3303 & $\begin{array}{l}\text { Geological observations on South America being the third part of } \\
\text { the Geology of the voyage of the Beagle under the command of } \\
\text { captain Fitzroy, R.N., during the years 1832 to 1836" }\end{array}$ & London, 1846 \\
\hline 328 & $\begin{array}{l}\text { Journal of researches into the natural history and geology of the } \\
\text { countries visited during the voyage of Beagle round the world }\end{array}$ & London, 1860 \\
\hline 1903 & $\begin{array}{l}\text { De l'origine des espèces ou les lois du progrès chez les êtres } \\
\text { organisés }\end{array}$ & Paris, 1862 \\
\hline Les plantes insectivores. & Paris, 1877 \\
\hline
\end{tabular}

Source: Record book of existing works in 1882. AHGM.

Although The origin does not make explicit references to the appearance of man - Darwin would only do this in The descent of man published in 1871 - the ideas about evolution it conveyed involved for humans, the existence of a common descent. In the years that followed, several titles were released on the question of prehistoric man, some of which supported the idea of evolution. Amongst others stand out Evidence as to man's place in nature (1863) by T. Huxley (1825-1895) the first book entirely devoted to human evolution, and Geological evidences of the antiquity of man (1863), by C. Lyell, of which the Geological Commission acquired the French translation published in 1864. In this work, Lyell showed his interest in the findings of Boucher Phertes and reviewed the main prehistoric human osteological findings, concluding that there had not been sufficient excavations in the great book of Nature, to reveal the missing links.

Júlio Henriques was perhaps the first Portuguese to elaborate on the problem of the appearance of man. He chose this theme for a dissertation, titled Antiquity of Man (1866) ${ }^{36}$, for the position of professor at the Faculty of Philosophy, University of Coimbra. Based on major archaeo-anthropological European findings, he addressed the evolution of the human species arguing that the origin of man could be explained by the theory of transformation that is so in agreement with the general plan of organization of living things and the paleontological facts, albeit otherwise defended by religious beliefs and many men of science. 
However, with regard to Portugal Henriques mentions only briefly the skeletons of Cabeço da Arruda (p. 12) without passing opinion on their antiquity. There is no reference to Ribeiro's flint and chipped quartzite, in spite of the fact that these finding date back to the first years of the sixties, therefore prior to the most important findings of the Abbot Bourgeois. Indeed, Ribeiro would only disclose the findings and the idea of the tertiary man at a congress in Brussels in 1872.

Despite the findings accumulated and all the discussions on the issue in international forums, at the dawn of the 1880s scientists were still far from reaching definitive conclusions on the issue of the tertiary man. Under this scenario, we cannot outright dismiss the idea that there could have been a particular effort, on the part of Carlos Ribeiro, to make sure that the observations and discoveries that contextualized "his" Anthropopitecus ribeiroiili reached Darwin in order to alert the naturalist to the prehistoric human remains on Portuguese soil.

This will certainly be the question to which there is no easy answer, since by decision of the author, the issues of the Estudos prehistoricos do not refer to the descriptions or news related to the tertiary or quaternary man, who once dwelt in our latitudes $(1878$, p. 3), which were, nevertheless, mentioned in the communication on the Tertiary formations.

Ribeiro was perhaps expecting some kind of support or comment that Darwin did not provide in the brief thank you note he sent. Indeed, this correspondence took place in the last years of both distinguished researchers lives and when Darwin, was already well known and internationally requested. Polite, he certainly was, but time and patience you would have possibly limited to matters that do not interest him more directly.

\section{Final note}

These two unpublished letters are a contribution to the understanding of the web of international relationships that were established in the second half of the nineteenth century between the members of the Geological Commission of Portugal and the most prominent figures and scientific institutions in the fields of Geology and of prehistoric Anthropology and Archaeology.

Although the letters' content may be thought of lesser importance, their finding in the epistolary collection of the Geological Commission deserves fair disclosure. It is not just about adding another name to the list of international correspondents of the pioneers of Portuguese geology; it is above all, to add the name of Charles Darwin to this long list.

\section{Aknowledgments}

The author wishes to thank William Darwin and to the editors of Darwin Correspondence Project for access to unpublished material, to LNEG the permission to reproduce one of the letters, to Rosy Clarkson (University of Cambridge) for her assistance and profs. Fátima Nunes, Margaret Lopes (University of Évora/Center for the Study of History and Philosophy of Science) and Pedro Callapez (Coimbra University) for the critical reading of the original text. 


\section{Notas e referências bibliográficas}

José Brandão is Ph.D. in History and Philosophy of Science, researcher at Centro de Estudos de História e Filosofia da Ciência, Universidade de Évora, Portugal.

E-mail: josembrandao@gmail.com.

1 DARWIN, Francis. La vie et la correspondance de Darwin avec un chapitre autobiographique. Tradução H. Varigny. Paris: C. Reinwald, 1888.

2 TAVARES, Carlos. Quatro cartas inéditas de Charles Darwin para Francisco d'Arruda Furtado. Revista da Faculdade de Ciências de Lisboa, v. 5, n. 2, p. $277-$ 302, 2ª́rie, 1957.

3 Provided by Darwin Correspondence Project, University of Cambridge.

4 RIBEIRO, Carlos. Estudos prehistoricos em Portugal. Noticia sobre algumas estações e monumentos prehistoricos. Secção I - Noticia da estação humana de Licêa, 1878; Secção II - Monumentos megalithicos das visinhanças de Bellas, 1880. Memória apresentada à Academia Real das Sciencias de Lisboa. Lisboa: Typographia da Academia.

5 We had confirmation of the existence of a copy of the first issue of Estudos in Darwin's library at Down House (pages uncut and without notes to a CD - DI: GREGORIO, M.; GILL, N. Charles Darwin's marginalia. New York: Garland Publisher, 1990). The question remains for the second, whose existence was not confirmed neither in Darwin's house nor at the University of Cambridge that houses a portion of his collection.

6 There is a copy of this book in the library of the University of Cambridge.

7 RIBEIRO, Carlos. Des formations tertiaires du Portugal. Extrait du Compte rendu sténographique du CONGRÈS INTERNATIONAL DE GÉOLOGIE DE PARIS, 1878.

8 RIBEIRO, Carlos. Sur des silex taillés découverts dans les terrais miocènes et pliocènes du Portugal. In: CONGRES INTERNATIONAL D'ANTHROPOLOGIE ET D'ARCHEOLOGIE PREHISTORIQUES. Compte rendu de la 6e. session. Bruxelles, 1872. p. 95-100. About the geology of the site see also from the same author: Sur la position géologique des couches miocènes et pliocènes du Portugal que contiennent des silex taillés. In: CONGRES INTERNATIONAL D'ANTHROPOLOGIE ET D'ARCHEOLOGIE PREHISTORIQUES. Compte rendu de la 6e. session. Bruxelles, 1872. p. 100-104.

9 See: CARNEIRO, Ana; LEITÃO, Vanda. Engineers and geological cartography in nineteenth-century Portugal with considerations on the professionalization of geologists. In: COLÓOUIO JOGOS DE IDENTIDADE: OS ENGENHEIROS, A FORMAÇÃO E A ACÇÃO. Portugal: Universidade de Évora, 2003; CARNEIRO, Ana; MOTA, T. Salomé. A tradição cartográfica nos serviços geológicos de Portugal, 1857-1961. Comunicações Geológicas, Lisboa, v. 92, p. 143-156, 2005.

10 BRANDÃO, José M. Museu Geológico: lugar de memórias históricas e científicas. In: SEMEDO, A.; NASCIMENTO, E. Actas do Seminário de Investigação em Museologia dos países de língua Portuguesa e espanhola. Porto, 2010. v. 1, p. 164-174.

11 RIBEIRO, Carlos. Note sur le terrain quaternaire du Portugal. Bulletin de la Société Géologique de France, Paris, n. 24, p. 692-717, $2^{\mathrm{a}}$ série, 1867.

12 Dated by Ribeiro as of the beginning "of polished stone age" (1878), these deposits came later to be ascribed to the Mesolithic. The osteological remains and other evidence of human activity, support the view of the Muge shell as one of the most important units internationally.

13 See: DELGADO, J. Nery. Da existencia do homem no nosso solo em tempos muito remotos provada pelo estudo das cavernas [On the existence of man on our soil in ancient times established by the study of caves]. Lisboa: Commissão Geologica de Portugal, 1867.

14 Later, N. Delgado, whilst admitting that in that period more attention might have been even paid to Archaeology than to Geology, he recognize (rightly) Ribeiro as the "initiator of prehistoric studies in Portugal" (DELGADO, J. Nery. Elogio histórico do general Carlos Ribeiro. Lisboa: Imprensa Nacional, 1905). It should be made clear, however, that despite the interest in these issues Ribeiro never neglected the issues of geological nature as P. Choffat (CHOFFAT, P. Notice nécrologique sur Carlos Ribeiro. Bulletin Société Géologique de France, n. 11, 3a série, 1882).

5 COSTA, Pereira da. On the existence of man in remote epochs in the Tagus Valley: News about the human skeletons discovered in the Cabeço da Arruda. Lisboa: Commissão Geológica de Portugal/Imprensa Nacional, 1865.

16 See RIBEIRO note 8.

17 DELGADO, op. cit.

18 See RIBEIRO, Carlos. Descripção de alguns silex e quatzites lascados encontrados nas camadas dos terrenos terciario e quaternario das bacias do Tejo e Sado. Lisboa: Commissão Geológica de Portugal, 1871.

19 RIBEIRO, Carlos. Descripção do terreno quaternario das bacias hydrographicas do Tejo e do Sado. Lisboa: Typographia da Academia das Sciencias, 1866

20 CHAUVIN, Jean. Un professeur original du collège de Pontlevoy: I'abbé Bourgeois. Mem. Acad. des Sciences, Arts et Belles Lettres de Touraine, v. 77 , p. 279-289, 2008.

21 MORTILLET, Gabriel. Sur I'homme tertiaire. Bulletin de la Société d'anthropologie de Paris, n. 8, 2ª série, p. 671-684, 1873.

22 See RIBEIRO note 8.

23 See RIBEIRO, op. cit. 1878; RIBEIRO, Carlos. Quelques mots sur l'âge de la pierre en Portugal. CONGRÈS DE PARIS [1878], Compte Rendu de la 7.e session Association Française pour l'Avancement des Sciences, p. 894-911, 1880.

24 RIBEIRO, C. L'homme tertiaire en Portugal. In: CONGRES INTERNATIONAL D'ANTHROPOLOGIE ET D'ARCHEOLOGIE PREHISTORIQUES. Compte rendu de la 9e. session. Lisbonne, Académie Royale des Sciences, p. 81-92, 1884.

25 Currently the Hall of Prehistoric Archaeology of Geological Museum of LNEG.

26 RIBEIRO, Carlos. Discours prononcé par M. Ribeiro, secrétaire générale à l'ouverture de la 9e session du Congrès International d'Anthropologie et d'Archéologies Préhistoriques en 1880. Lisbonne: Académie Royale des Sciences, 1884.

27 CHOFFAT, op. cit., p. 321-329.. Delgado would later write (op. cit., 1905, p. 34) about this issue that "The truth... is that the question of Tertiary man is still undecided, and if the discovery made ten years ago by Dubois in the Trinil Pliocene, on the island of Java, seems to be solving the problem, the fact remains that the idea of the existence of a precursor of man be in the Tertiary era has lost much ground".

The issue of tertiary Portuguese man would only be resolved in the mid-forties (twentieth century), with the studies of Henry and Georges Breuil Zbyszewski. 
See: CARDOSO, João L. As investigações de Carlos Ribeiro e de Nery Delgado sobre o 'Homem do terciário': resultados e consequências na época e para além dela. Estudos Arqueológicos de Oeiras, v. 8, p. 33-54, 2000.

29 See: CATALÁ-GORGUES, Jesús; CARNEIRO, Ana. Like birds of a feather: The cultural origins of Iberian geological cooperation and the European Geological Map of 1896. The British Journal for the History of Science. Disponivel em: <CJO 2011 doi:10.1017/S0007087411000306>.

30 Until the introduction of K. Zittel's systematic (1839-1904) by P. Choffat, works of reference for the classification and organization of the materials collected were those of the major French naturalists, namely the treaty and the prodrome of Alcide D’Orbigny (1802-1857).

31 GOODRUM, M. R. The history of human origins research and its place in the history of science: Research problems and historiography. History of Science, v. 47 , p. p. 337-357, 2009.

32 This evidence cannot be taken as decisive as the Repartição de Minas (Bureau of Mines) continued beyond 1857 and supervised the Geological Commission; hence the book might have been purchased at a later date.

33 See ALMAÇA, Carlos. O Darwinismo na universidade portuguesa. Lisboa: Museu Antropológico e Zoológico (Museu Bocage), 1999. We cannot entirely reject the hypothesis that the route to such knowledge had been Daniel Sharpe (1806-1856), an English merchant, member of the Royal Society and Darwin correspondent, who spent some time in Portugal and with whom Ribeiro maintained professional contacts.

34 This is possibly the first edition of the translation. A reference to this work appears in the book annexes to the entry books of library acquisitions as being "in possession of Mr. Carlos Ribeiro." Unfortunately, this copy is lost.

35 There is a copy of the 1864 edition in the library of Geological section of the works, as well as a copy of the annotated French translation by DALLY, E. De la place de l'homme dans la nature. Paris: J.-B. Baillière et Fils, 1868.

36 HENRIQUES, J. Antiguidade do homem. Portugal: Imprensa da Universidade de Coimbra, 1866.

37 Name given by G. Mortillet to the creature that produced the "industries" collected by Ribeiro in the Tagus Valley.

[Recebido em junho de 2011, aprovado para publicação em outubro de 2011] 